\title{
Chronic radiation proctitis: tricks to prevent and treat
}

\author{
Ben G. L. Vanneste ${ }^{1} \cdot$ Lien Van De Voorde ${ }^{1} \cdot$ Rogier J. de Ridder $^{2} \cdot$ \\ Evert J. Van Limbergen ${ }^{1}$ Philippe Lambin ${ }^{1} \cdot$ Emile N. van Lin ${ }^{1}$
}

Accepted: 13 June 2015 / Published online: 23 July 2015

(C) The Author(s) 2015. This article is published with open access at Springerlink.com

\begin{abstract}
Objective The purpose of this study was to give an overview of the measures used to prevent chronic radiation proctitis (CRP) and to provide an algorithm for the treatment of CRP. Methods Medical literature databases including PubMed and Medline were screened and critically analyzed for relevance in the scope of our purpose.

Results CRP is a relatively frequent late side effect (5-20\%) and mainly dependent on the dose and volume of irradiated rectum. Radiation treatment (RT) techniques to prevent CRP are constantly improving thanks to image-guided RT and intensity-modulated RT. Also, newer techniques like protons and new devices such as rectum spacers and balloons have been developed to spare rectal structures. Biopsies do not contribute to diagnosing CRP and should be avoided because of the risk of severe rectal wall damage, such as necrosis and fistulas. There is no consensus on the optimal treatment of CRP. A variety of possibilities is available and includes topical and oral agents, hyperbaric oxygen therapy, and endoscopic interventions.

Conclusions CRP has a natural history of improving over time, even without treatment. This is important to take into account when considering these treatments: first be conservative (topical and oral agents) and be aware that invasive treatments can be very toxic.
\end{abstract}

Ben G. L. Vanneste

ben.vanneste@maastro.nl

1 Department of Radiation Oncology (MAASTRO Clinic), GROW-School for Oncology and Developmental Biology, Maastricht University Medical Center, P.O. Box 3035, 6202 NA Maastricht, The Netherlands

2 Department of Gastroenterology, Maastricht University Medical Center, Maastricht, The Netherlands
Keywords Radiotherapy $\cdot$ Radiation proctitis $\cdot$ Prevention · Treatment

\section{Introduction}

Radiation injury to the rectum represents a feared complication of radiotherapy (RT) in urological, gynecological, and gastrointestinal malignancies (prostate, urinary bladder, cervix, uterus, and anus). Chronic radiation proctitis (CRP) is a relatively frequent late (after 3-6 months) side effect that affects 5-20\% of cancer patients [1-3]. The probability of developing the injury is related to the volume of rectum irradiated, total RT dose, RT technique, and dose per fraction [4]. Also, individual patient factors can influence the susceptibility to CRP: comorbidity of vascular disease, diabetes, connective tissue disease or inflammatory bowel disease, specific conditions such as smoking, and concomitant chemotherapy [5, 6]. Published nomograms based on patient risk factors (use of anti-coagulants, hormonal therapy, or anti-hypertensives; presence of diabetes or hemorrhoids, and a history of pre-RT abdominal surgery) have been predictive for CRP in prostate cancer $[7,8]$.

Until now, no optimal management has been defined for CRP. A variety of therapeutic modalities is available ranging from oral agents to endoscopic interventions. The aim of this article is to summarize the measures being developed for the prevention of CRP and to present a practical algorithm for the treatment of CRP based on a review of the literature.

\section{Symptoms}

RT can cause both early (acute) and late (chronic) side effects [9]. Acute side effects by definition occur up to 3 months after RT and are usually self-limiting. Chronic side effects occur 3- 
Table 1 Radiation proctitis according to the 'common toxicity criteria', version 4

\begin{tabular}{ll}
\hline Grade CRP & Symptoms \\
\hline 1 & Rectal discomfort; intervention not indicated \\
2 & $\begin{array}{c}\text { Symptoms (rectal discomfort, passing blood } \\
\text { or mucus); medical intervention indicated; } \\
\text { limiting instrumental ADL }\end{array}$ \\
3 & Severe symptoms; fecal urgency or stool \\
& incontinence; limiting self-care ADL \\
4 & Life-threatening consequences; urgent \\
& intervention indicated \\
5 & Death \\
\hline
\end{tabular}

6 months after RT or even years later. The side effects of RT are scored in five groups (see Table 1) according to the National Cancer Institute Common Terminology Criteria for Adverse Events 4.0 (CTCAE) [10]. Acute side effects include diarrhea, mucus discharge, urgency, tenesmus, and uncommonly bleeding [5]. Similar symptoms are seen in patients with chronic CRP, but bleeding is the most common symptom, with potential iron-deficiency anemia that requires blood transfusions. In addition, patients may have symptoms of obstructed defecation due to strictures with symptoms of constipation, rectal pain, urgency, and, rarely, fecal incontinence due to overflow [5]. In a series of studies, Andreyev et al. identified 23 different symptoms that develop after pelvic RT [11-13].

\section{Pathogenesis}

CRP results from progressive epithelial atrophy and fibrosis associated with obliterative endarteritis, chronic mucosal ischemia, submucosal fibrosis, and new vessel formation, which have been shown to lead to clinical symptoms [14]. This is not further discussed here because they go beyond the scope of this article and can be found elsewhere $[14,15]$.

\section{Diagnosis}

CRP should be suspected in any patient who has had pelvic RT and presents with the symptoms mentioned above, even if the radiotherapy took place years ago. Diagnosis by endoscopy is important to exclude other causes of proctitis (infectious colitis, inflammatory bowel disease, diversion colitis, ischemic colitis, diverticular colitis) and a second malignancy [15].

Endoscopy is also important to determine the extent and severity of CRP. There are three main forms of endoscopic findings in CRP: inflammation predominant form (I-CRP) (edema, mucosal pallor, and ulcer), bleeding predominant form (B-CRP) (friability, spontaneous hemorrhage, and telangiectasia), and a mixed form (with features from both I-CRP and B-CRP) (Fig. 1a-d) [15-17]. The endoscopic classification of CRP is usually analyzed by the Vienna Rectoscopy Score (VRS) to describe rectal mucosa [18]. The VRS divides the inner rectal mucosa into 12 mucosal areas. Furthermore, each area is scored on the presence and grading of telangiectasia (Grade 0-3), congested mucosa (Grade 0-3), ulceration (Grade 0-4), stricture (Grade 0-4), and necrosis (Grade 0-1). However, other scoring systems also exist [19].

Rectal wall biopsies should be avoided as they may initiate chronic, poorly healing wounds. A number of studies have also described fistula formation over the prostate following rectal biopsies [20-22]. Therefore, a biopsy is only justified if a malignancy is suspected or in case of important therapeutic consequences. In these cases, biopsies should be taken from the posterior and lateral rectal walls to avoid the anterior irradiated high-dose areas [20]. In conclusion, biopsies do not really contribute to the diagnosis of CRP and should be avoided.

\section{Prevention}

Excluding the rectum from the irradiation fields to prevent CRP has a high priority in RT. Optimizing the RT planning by using planning constraints reduces the irradiated rectal volume and consequently decreases the risk of rectal toxicity [23].

There is increasing evidence supporting the role of genetic variants in the development of RT-induced toxicity [24]. Recently, the first replicated genetic associations for adverse reactions to RT were reported [25]. Active research to identify high-risk patients is based on genetic biomarkers [26] that could allow radiotherapists to select patients for which extra care should be taken to decrease the dose to the rectum.

\section{Different RT techniques}

The use of modern RT techniques (intensity-modulated RT) and the use of implanted fiducial markers into the prostate (image-guided RT) minimize the dose of radiation to the rectum while maximizing the dose to the prostate [27-29].

Newer RT techniques which utilize heavy particles such as protons and carbon ions are currently being developed and tested to improve outcomes with reduced toxicity [30, 31]. Carbon ions seem to be better protective than protons which can be explained by the steeper dose gradients achieved by heavier particles [32]. Although these methods have the potential to deliver optimal doses of radiation to the tumor with only minimal exposure to the surrounding normal tissues, the long-term outcomes are not yet clear. 
Fig. 1 Endoscopic features illustrating the different grades of $\mathrm{CRP}$ at the anterior rectum wall. a shows CRP with edematous and multiple non-confluent telangiectatic lesions, $\mathbf{b}$ demonstrates a predominantly bleeding form of CRP, $\mathbf{c}$ illustrates necrosis with multiple confluent telangiectatic lesions, and $\mathbf{d}$ shows an ulcer
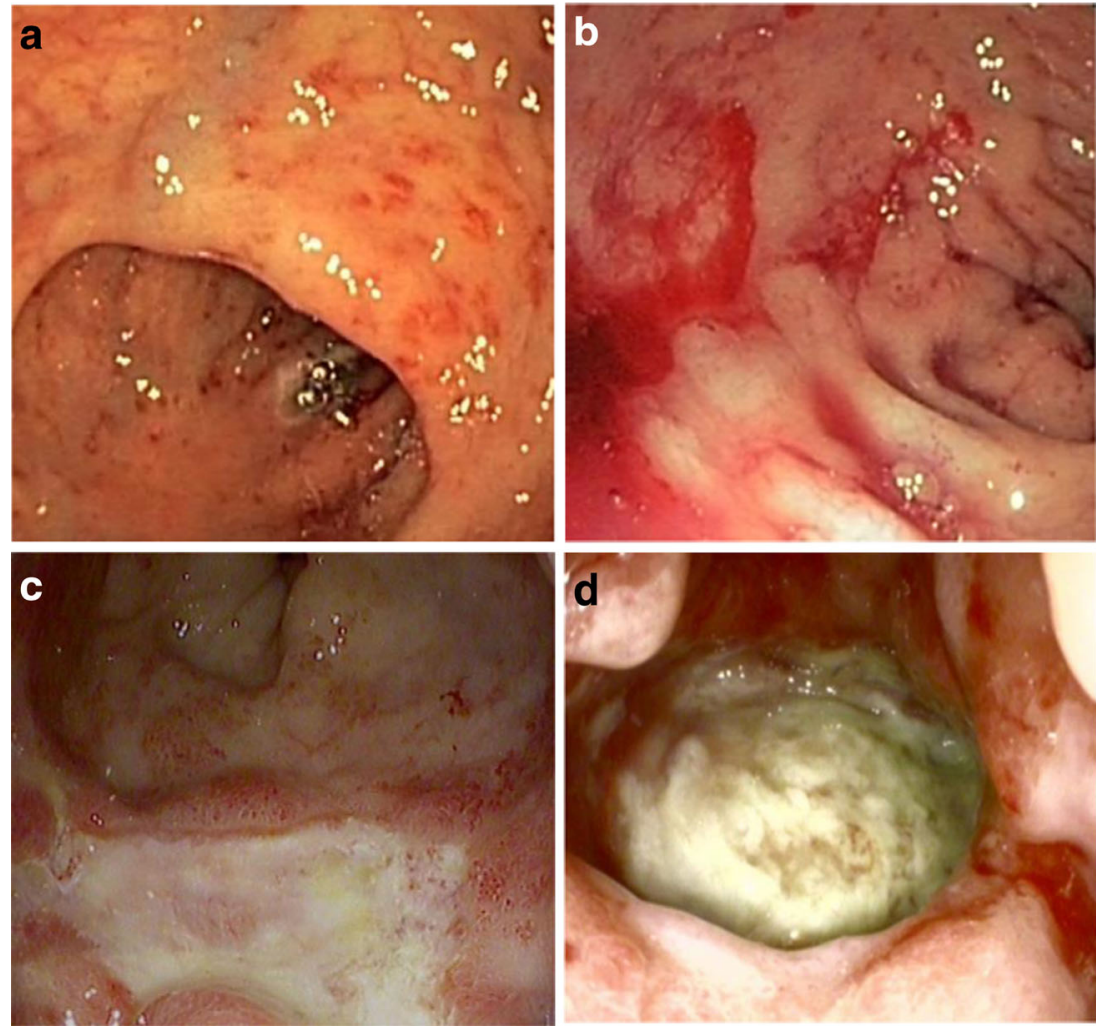

\section{Medication}

The use of medical therapy (amifostine, sucralfate, 5aminosalicylic acid, or sulphasalazine) to prevent the development of CRP has only a minimal effect and is not widely used [33-36]. Placebo-controlled phase III trials have shown no benefit from either topical or oral sucralfate [37]. However, higher doses of amifostine are described as tolerable and as having a better protective effect against the early and late short-term effects of RT [38].

Newer insights have revealed that synbiotics and microbiotics can be used to manipulate the intestinal flora to prevent and treat CRP [39, 40]. Further research is needed to confirm those preliminary data.

\section{Rectum spacer}

Devices have been developed to spare rectal structures [41]. These can be divided into endorectal balloons and relatively novel rectum spacers. Endorectal balloons are inserted into the rectum for each daily treatment fraction to increase the distance from the dorsal rectal wall to the prostate. Although the anterior anorectal wall is pushed towards the prostate, the overall effect proved to be beneficial in 3D-conformal RT and intensity-modulated RT [42]. Rectum spacers are implanted as a tissue filler into the anterior perirectal fat to separate the rectum from the prostate (Fig. 2). Increasing the prostate-rectum distance displaces the rectal wall away from the prostate and out of the regions of high-dose RT. The overall effect is a reduction in the maximum dose to the rectum and the total volume of irradiated rectum. The implantation of such rectum spacers is typically performed transperineally under real-time transrectal ultrasound guidance. The insertion procedure can be performed under local (with or without sedation), spinal, or general anesthesia [43]. The implanted rectum spacer remains in place over the course of the RT treatment, and the spacer biodegrades naturally within 6 months after implantation [44]. Different types of rectum spacers have been developed: an absorbable hydrogel, a hyaluronic acid, a collagen, and a saline-filled balloon [44-46]. Several studies are available on the dosimetry, acute outcome, and cost-effectiveness of a rectum spacer; however, no long-term results are available yet [47-56].

\section{Treatment}

A wide variety of interventions have been tried for treating CRP. There have been no large controlled randomized trials to evaluate the treatment of CRP. Also, several studies have resulted in ambiguous outcome measurements, showing no structured outcome measurement to describe and compare the findings from different trials. Some studies used the 
Fig. 2 Axial T2-weighted magnetic resonance images of a patient with a hydrogel spacer before injection (a) and after injection (b)
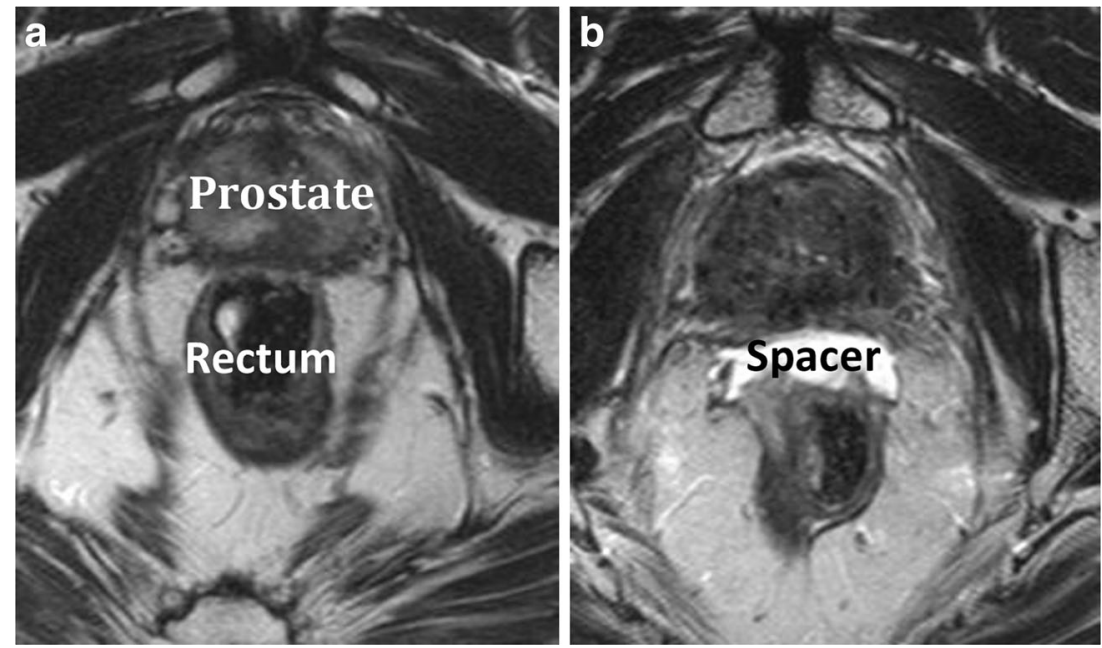

VRS scoring system to evaluate treatments; others used different clinical outcomes. Thus, experience is derived mostly from small clinical trials, expert opinions, and case reports $[57,58]$. Interventions can broadly be categorized into medical therapies, endoscopic therapies, and surgical interventions. Medical therapy is the main stay of treatment for I-CRP. Endoscopy is the main treatment modality for B-CRP if the bleeding is affecting quality of life [15]. It is very important to realize, when considering invasive treatments, that CRP can improve over time without any active treatment [59].

In patients with CRP, treatment should be based upon the pattern and severity of symptoms and experience at the treatment center. A treatment algorithm is presented in Fig. 3 for this purpose. For patients with minor symptoms that do not affect their quality of life, no treatment may be indicated because CRP has a natural history of improving over time without treatment. For patients with I-CRP, Andreyev et al. published a treatment guide that recommends loperamide, fibers, stoolbulking agents, and corticosteroids [13]. Patients with B-CRP and physical complaints of anemia (dyspnoe d'effort, palpitations, fatigue) should be monitored for anemia and where appropriate given iron supplements or blood transfusion. If necessary, endoscopic treatment is also indicated [60]. B-CRP is the most common form, and therefore, most studies have concentrated and published on B-CRP.

\section{Medical treatment of B-CRP}

Medical treatments with level I evidence of benefits in small randomized trials are listed here: sucralfate enema [61, 62], metronidazole [63], vitamin A [64], and hyperbaric oxygen therapy (HOT) [65].

\section{Sucralfate enema}

Sucralfate is an aluminum salt that adheres to mucosal cells and stimulates prostaglandin production, producing cytoprotective effects. It has been used in the treatment of peptic ulcers [66].

In a prospective randomized trial, Kochhar et al. reported 37 patients with RT-induced CRP who were assigned to a 4week course of sulfasalazine ( $3 \mathrm{~g} /$ day) plus prednisolone enemas (20 mg $2 \times /$ day) or sucralfate enemas ( $\mathrm{g} 2 \times /$ day) [61].

Kochhar et al. subsequently reported in a prospective study on 26 patients with moderate to severe CRP who were treated with $20-\mathrm{ml}$ sucralfate enemas twice daily until bleeding stopped or failure of therapy was acknowledged. Response to the therapy was considered good when the severity of bleeding improved by two grades. This was observed in $77 \%$ of patients [62]. Kochhar et al. concluded that sucralfate enemas give a better clinical response and are better tolerated.

Although placebo-controlled randomized trials are needed to fully assess efficacy, sucralfate is recommended as the preferred mode of short-term treatment.

\section{Metronidazole}

Anti-microbial agents could be effective in CRP because of their immune-modulatory effects [67] and selective toxicity to microorganisms that contribute to the pathogenesis of CRP [68].

Cavcic et al. reported on 60 patients with CRP who received mesalazine ( $1 \mathrm{~g} 3 \times /$ day $)$ and a betamethasone enema (1/day during 4 weeks) with or without oral metronidazole (400 mg 3×/day) [63]. The addition of metronidazole was associated with a reduction in rectal bleeding, diarrhea, and ulcers at 4 weeks, 3 months, and 12 months. This trial 
Fig. 3 Algorithm for treatment of CRP

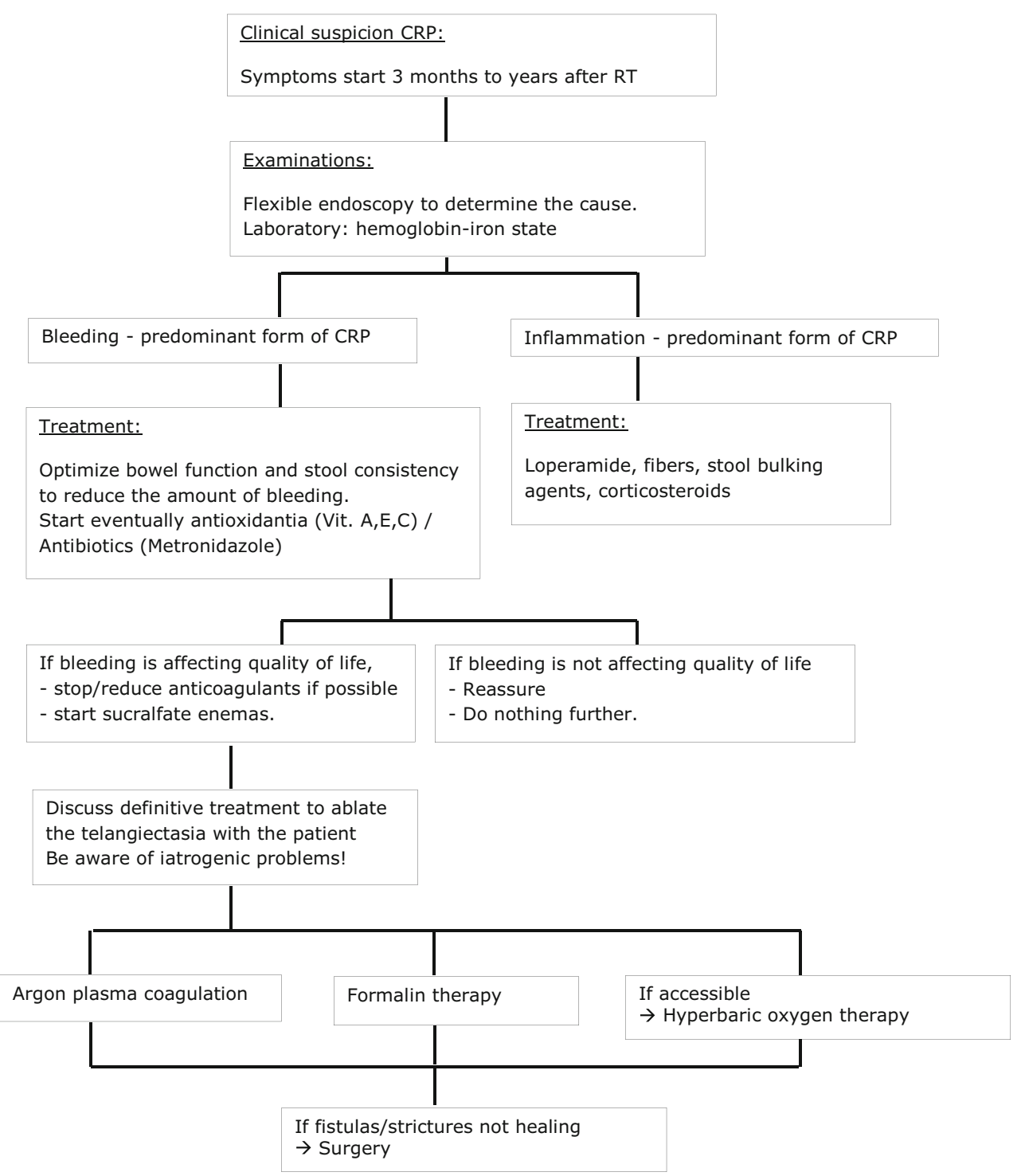

suggested that metronidazole can improve symptoms and mucosal healing in combination with anti-inflammatory treatments.

\section{Vitamin $A / E / C$}

Antioxidants were suggested to have cytoprotective effects by reducing cellular oxidative stress following radiation injury to intestinal tissue [69].

Ehrenpreis et al. reported on a prospective double-blind trial including 19 patients with CRP 6 months after RT who were randomized to receive oral vitamin A (10,000 IU 2×/day, during 90 days) or a placebo. Vitamin A significantly reduced rectal symptoms of CRP [64].

Kennedy et al. reported on 20 patients treated for symptomatic CRP with oral vitamin E (400 IU $3 \times /$ day) and vitamin $\mathrm{C}$ (500 mg $3 \times /$ day). Bleeding resolved in 4 of 11 patients, and diarrhea resolved in $50 \%$ of patients [70].
Hyperbaric oxygen therapy

HOT involves patients breathing pure oxygen in a pressurized room or tube. In a HOT chamber, the air pressure is increased to three times higher than normal air pressure [71]. Under these conditions, the lungs can gather more oxygen than at normal air pressure. This higher oxygenated blood may be beneficial because it inhibits bacterial growth and stimulates the release of growth factors and stem cells, which promotes wound healing. It may even reverse progressive changes caused by RT and may improve other symptoms such as urinary problems [72, 73].

Clarke [65] performed a controlled randomized trial with groups that were randomized to HOT at $2.0 \mathrm{~atm}$ absolute or air at $1.1 \mathrm{~atm}$ absolute. HOT significantly improved the healing responses in patients with refractory CRP, generating an absolute risk reduction of $32 \%$ (number needed to treat, 3) [65]. 
A Cochrane review revealed a significantly increased chance of improvement or cure following HOT for CRP (RR $1.72 ; 95 \%$ CI 1.0 to $2.9, p$ 0.04) [74].

Unfortunately, hyperbaric oxygen facilities are not always available, so patients may need to travel long distances to their nearest unit, and treatments are time-consuming (60-120 min for 30-70 sessions) and expensive [75].

\section{Endoscopic treatment}

A variety of endoscopic therapies is available for rectal bleeding caused by CRP including argon plasma coagulation (APC), topical formalin, laser, heater, and bipolar probes. There is no level I evidence of benefit in randomized trials. The goal of endoscopic treatments of CRP is to control bleeding. Endoscopic treatments may require multiple procedures and can have very significant adverse effects [60]. Due to a known high-potential risk of fistulas and ulcerations in the first 2 years after RT, we advise that all endoscopic treatments should be performed by an experienced gastroenterologist with particular awareness of post-RT rectal injury in close collaboration with a pelvic radiation oncologist [76].

\section{Argon plasma coagulation}

APC is a form of electrocautery, in which a monopolar diathermy is transmitted to the target tissue through an ionized gas in a non-contact fashion (0.8-3.0 $\mathrm{mm}$ from the target) [77]. APC is considered by many gastroenterologists as the treatment of choice for CRP [78-81]. However, it should be used with caution in this patient group. Complications such as bowel explosions following the use of APC in inadequately prepared bowels have been described but are preventable [82]. Other severe side effects, such as the occurrence of deep ulceration [83, 84], fistulation [85], stricture formation [86-88], bleeding [83, 84, 89], perforation [83], and severe and sometimes chronic pain $[80,89,90]$, reflect the risk of any therapy in chronically ischemic tissues. Rectal ulcers after APC when used for CRP are observed in approximately $26 \%$ of patients, in one series, even up to $52 \%$ [91-93]. Together with restricting argon flow rates and wattage, a very precise and brief application of the argon catheter could potentially reduce complication rates [94]. In specialist centers, serious complications of previous APC treatment in this patient group continue to be seen regularly [60].

Swan et al. presented a complete resolution of bleeding in $72 \%$ of 50 patients who had bleeding CRP [79]. Thirty-four percent of the patients experienced short-term, self-limiting complications; $2 \%$ experienced a long-term complication. The setting was a tertiary referral hospital, where only dedicated and experienced gastroenterologists were involved in post-RT rectal injury.

\section{Topical formalin}

Formalin seals fragile neovasculature in radiation-damaged tissues to prevent further bleeding through chemical cauterization $[95,96]$. This treatment is simple to perform, but a severe disadvantage is a chemical burn to the skin if there is spillage [60].

There are several small retrospective studies on the use of formalin. These studies used a variety of formalin application techniques, from irrigation to direct application, and formalin concentrations, from 3.6 to $10 \%$ [97]. The short-term success rate of this technique ranged from 60 to $100 \%$ [98-109]. However, the procedure is not risk free and may induce major complications such as acute colitis [110].

Yeoh et al. showed that APC and topical formalin had comparable efficacy in the durable control of rectal bleeding associated with CRP but had no beneficial effect on anorectal dysfunction [111]. However, more authors reported that APC may be more effective in treating CRP as compared with formalin therapy $[58,89,112]$.

\section{Laser}

The argon and neodymium/yttrium aluminum garnet (Nd:YAG) laser has been used to coagulate bleeding vessels throughout the gastrointestinal tract [113]. A study that included 65 patients treated with an Nd:YAG laser found an improvement in symptoms in $78 \%$ of patients (range, 58 to $87 \%$ ) [114]. However, the laser is expensive and not widely available.

Assessing the effectiveness of these interventions is complicated by the small number of patients included in many trials, the lack of a control arm, and the fact that the natural history of CRP is to improve over time without treatment.

\section{Surgery}

Surgery is considered as a last resort for patients with CRP and should be reserved for those who are found to have a stricture, permanent bleeding, perforation, or a fistula that is not responsive to the medical and endoscopic approaches $[15,115]$. Surgical treatment options include excision, urinary and fecal diversion (diverting stoma), and reconstruction of a coloanal $\mathrm{J}$ reservoir [116]. Severe postoperative complications can occur such as sepsis, wound dehiscence, bowel obstruction, and de novo rectal fistula [76]. Yegappan et al. reported a $3 \%$ postoperative mortality rate [117].

Fischer et al. concluded that $51 \%$ of their participants had a fair outcome, $34 \%$ had slight or moderate symptoms, and $14 \%$ had disabling symptoms [118]. Lane et al. revealed that good outcomes can be expected in properly selected patients [119]. Turina et al. determined that the best results were found in patients presenting with colorectal anastomotic and primary 
bowel strictures as their main complication, while most patients with severe CRP and very distal strictures required permanent diversion [120].

\section{Conclusion}

CRP is a commonly observed late side effect of pelvic RT and can occur even years after treatment. First of all, care should be taken to minimize the risk of CRP by improving RT techniques (IMRT, IGRT) or to implement new devices to spare the rectum (spacers, balloons). On the basis of the available knowledge, we constructed a practical management algorithm (Fig. 3). The literature generally recommends a flexible endoscopy to determine the cause. Biopsy, and especially anterior rectal biopsy, within the first years of RT should be avoided, because this augments the risk of a fistula and is not likely to provide any relevant information.

There are three main forms of CRP: I-CRP, B-CRP, and a mixed form. I-CRP responds well to loperamide, fibers, stoolbulking agents, and corticosteroids. B-CRP is often selflimiting and responds well to conservative management; it is advisable to stop anti-coagulants, if possible, and start with antioxidants (vitamin A, E, C) and/or antibiotics (metronidazole). If no response is observed, patients should be started on sucralfate enemas. In severe cases, with persistent bleeding, chemical (formalin) or thermal (coagulation) treatments are successful. If HOT is available, it may also be a good option. Surgery should be considered as the last resort and is only indicated if fistulas and strictures are not healing. Although surgery can lead to significant improvements, it also bears an increased risk of postsurgical complications. Based on the frequency of CRP, prospective controlled and larger studies are advised to increase our knowledge about both the prevention and treatment of CRP.

Open Access This article is distributed under the terms of the Creative Commons Attribution 4.0 International License (http:// creativecommons.org/licenses/by/4.0/), which permits unrestricted use, distribution, and reproduction in any medium, provided you give appropriate credit to the original author(s) and the source, provide a link to the Creative Commons license, and indicate if changes were made.

\section{References}

1. Garg AK, Mai WY, McGary JE, Grant WH 3rd, Butler EB, Teh BS (2006) Radiation proctopathy in the treatment of prostate cancer. Int J Radiat Oncol Biol Phys 66(5):1294-1305. doi:10.1016/j. ijrobp.2006.07.1386

2. Kuku S, Fragkos C, McCormack M, Forbes A (2013) Radiationinduced bowel injury: the impact of radiotherapy on survivorship after treatment for gynaecological cancers. Br J Cancer 109(6): 1504-1512. doi:10.1038/bjc.2013.491
3. Krol R, Smeenk RJ, van Lin EN, Yeoh EE, Hopman WP (2014) Systematic review: anal and rectal changes after radiotherapy for prostate cancer. Int J Color Dis 29(3):273-283. doi:10.1007/ s00384-013-1784-8

4. Talcott JA, Manola J, Clark JA, Kaplan I, Beard CJ, Mitchell SP, Chen RC, O'Leary MP, Kantoff PW, D'Amico AV (2003) Time course and predictors of symptoms after primary prostate cancer therapy. J Clin Oncol 21(21):3979-3986. doi:10.1200/JCO.2003. 01.199

5. Shadad AK, Sullivan FJ, Martin JD, Egan LJ (2013) Gastrointestinal radiation injury: symptoms, risk factors and mechanisms. World J Gastroenterol 19(2):185-198. doi:10. 3748/wjg.v19.i2.199

6. Theis VS, Sripadam R, Ramani V, Lal S (2010) Chronic radiation enteritis. Clin Oncol (R Coll Radiol) 22(1):70-83. doi:10.1016/j. clon.2009.10.003

7. Valdagni R, Rancati T, Fiorino C, Fellin G, Magli A, Baccolini M, Bianchi C, Cagna E, Greco C, Mauro FA, Monti AF, Munoz F, Stasi M, Franzone P, Vavassori V (2008) Development of a set of nomograms to predict acute lower gastrointestinal toxicity for prostate cancer 3D-CRT. Int J Radiat Oncol Biol Phys 71(4): 1065-1073. doi:10.1016/j.ijrobp.2007.11.037

8. Valdagni R, Kattan MW, Rancati T, Yu C, Vavassori V, Fellin G, Cagna E, Gabriele P, Mauro FA, Baccolini M, Bianchi C, Menegotti L, Monti AF, Stasi M, Giganti MO, Fiorino C (2012) Is it time to tailor the prediction of radio-induced toxicity in prostate cancer patients? Building the first set of nomograms for late rectal syndrome. Int J Radiat Oncol Biol Phys 82(5):1957-1966. doi:10.1016/j.ijrobp.2011.03.028

9. Dörr W (2015) Radiobiology of tissue reactions. Ann ICRP. doi: $10.1177 / 0146645314560686$

10. National Cancer Institute (2013) Common Terminology Criteria for Adverse Events (CTCAE) 4.0. http://ctep.cancer.gov/ protocolDevelopment/electronic_applications/ctc.htm. Accessed 18 May 2015

11. Gami B, Harrington K, Blake P, Dearnaley D, Tait D, Davies J, Norman AR, Andreyev HJ (2003) How patients manage gastrointestinal symptoms after pelvic radiotherapy. Aliment Pharmacol Ther 18(10):987-994. doi:10.1046/j.1365-2036.2003.01760.x

12. Gillespie C, Goode C, Hackett C, Andreyev HJ (2007) The clinical needs of patients with chronic gastrointestinal symptoms after pelvic radiotherapy. Aliment Pharmacol Ther 26(4):555-563. doi: 10.1111/j.1365-2036.2007.03405

13. Andreyev HJ, Benton BE, Lalji A, Norton C, Mohammed K, Gage H, Pennert K, Lindsay JO (2013) Algorithm-based management of patients with gastrointestinal symptoms in patients after pelvic radiation treatment (ORBIT): a randomised controlled trial. Lancet 382(9910):2084-2092. doi:10.1016/s0140-6736(13) 61648-7

14. Leiper K, Morris AI (2007) Treatment of radiation proctitis. Clin Oncol (R Coll Radiol) 19(9):724-729. doi:10.1016/j.clon.2007. 07.008

15. Wu XR, Liu XL, Katz S, Shen B (2015) Pathogenesis, diagnosis, and management of ulcerative proctitis, chronic radiation proctopathy, and diversion proctitis. Inflamm Bowel Dis 21(3): 703-715. doi:10.1097/mib.0000000000000227

16. Moore EM, Magrino TJ, Johnstone PA (2000) Rectal bleeding after radiation therapy for prostate cancer: endoscopic evaluation. Radiology 217:215-218. doi:10.1148/radiology.217.1. r00oc24215

17. Reichelderfer M, Morrissey JF (1980) Colonoscopy in radiation colitis. Gastrointest Endosc 26:41-43. doi:10.1016/s00165107(80)73265-0

18. Wachter S, Gerstner N, Goldner G, Potzi R, Wambersie A, Potter R (2000) Endoscopic scoring of late rectal mucosal damage after 
conformal radiotherapy for prostatic carcinoma. Radiother Oncol 54(1):11-19. doi:10.1016/s0167-8140(99)00173-5

19. Chi KD, Ehrenpreis ED, Jani AB (2005) Accuracy and reliability of the endoscopic classification of chronic radiation-induced proctopathy using a novel grading method. J Clin Gastroenterol 39(1):42-46

20. Chrouser KL, Leibovich BC, Sweat SD, Larson DW, Davis BJ, Tran NV, Zincke H, Blute ML (2005) Urinary fistulas following external radiation or permanent brachytherapy for the treatment of prostate cancer. J Urol 173(6):1953-1957. doi:10.1097/01.ju. 0000158041.77063.ff

21. Theodorescu D, Gillenwater J, Koutrouvelis P (2000) Prostatourethral-rectal fistula after prostate brachytherapy. Cancer 89:2085-2091. doi:10.1002/1097-0142(20001115) 89:10<2085::aid-cncr8>3.0.co;2-q

22. Thornhill JA, Long RM, Neary P, O'Connor HJ, Ryan B, Fraser I (2012) The pitfalls of treating anorectal conditions after radiotherapy for prostate cancer. Ir Med J 105:91-93

23. Fonteyne V, De Neve W, Villeirs G, De Wagter C, De Meerleer G (2007) Late radiotherapy-induced lower intestinal toxicity (RILIT) of intensity-modulated radiotherapy for prostate cancer: the need for adapting toxicity scales and the appearance of the sigmoid colon as co-responsible organ for lower intestinal toxicity. Radiother Oncol 84(2):156-163. doi:10.1016/j.radonc.2007.06. 013

24. West C, Azria D, Chang-Claude J, Davidson S, Lambin P, Rosenstein B, De Ruysscher D, Talbot C, Thierens H, Valdagni R, Vega A, Yuille M (2014) The REQUITE project: validating predictive models and biomarkers of radiotherapy toxicity to reduce side-effects and improve quality of life in cancer survivors. Clin Oncol (R Coll Radiol) 26(12):739-742. doi:10.1016/j.clon. 2014.09.008

25. Fachal L, Gómez-Caamaño A, Barnett GC, Peleteiro P, Carballo AM, Calvo-Crespo P, Kerns SL, Sánchez-García M, LobatoBusto R, Dorling L, Elliott RM, Dearnaley DP, Sydes MR, Hall E, Burnet NG, Carracedo Á, Rosenstein BS, West CM, Dunning AM, Vega A (2014) A three-stage genome-wide association study identifies a susceptibility locus for late radiotherapy toxicity at 2q24.1. Nat Genet 46(8):891-894. doi:10.1038/ng.3020

26. West CM, Barnett GC (2011) Genetics and genomics of radiotherapy toxicity: towards prediction. Genome Med 3(8):52. doi:10. 1186/gm268

27. Zelefsky MJ, Fuks Z, Hunt M, Yamada Y, Marion C, Ling CC, Amols H, Venkatraman ES, Leibel SA (2002) High-dose intensity modulated radiation therapy for prostate cancer: early toxicity and biochemical outcome in 772 patients. Int J Radiat Oncol Biol Phys 53:1111-1116. doi:10.1016/s0360-3016(02)02857-2

28. De Meerleer GO, Fonteyne VH, Vakaet L, Villeirs GM, Denoyette L, Verbaeys A, Lummen N, De Neve WJ (2007) Intensitymodulated radiation therapy for prostate cancer: late morbidity and results on biochemical control. Radiother Oncol 82:160 166. doi:10.1016/j.radonc.2006.12.007

29. Wortel RC, Incrocci L, Pos FJ, Lebesque JV, Witte MG, van der Heide UA, van Herk M, Heemsbergen WD (2015) Acute toxicity after image-guided intensity modulated radiation therapy compared to 3D conformal radiation therapy in prostate cancer patients. Int J Radiat Oncol Biol Phys 91(4):737-744. doi:10.1016/ j.ijrobp.2014.12.017

30. Zietman A (2013) Proton beam and prostate cancer: an evolving debate. Rep Pract Oncol Radiother 18(6):338-342. doi:10.1016/j. rpor.2013.06.001

31. Shioyama Y, Tsuji H, Suefuji H, Sinoto M, Matsunobu A, Toyama S, Nakamura K, Kudo S (2015) Particle radiotherapy for prostate cancer. Int J Urol 22(1):33-39. doi:10.1111/iju.12640

32. Georg D, Hopfgartner J, Gòra J, Kuess P, Kragl G, Berger D, Hegazy N, Goldner G, Georg P (2014) Dosimetric considerations to determine the optimal technique for localized prostate cancer among external photon, proton, or carbon-ion therapy and highdose-rate or low-dose-rate brachytherapy. Int J Radiat Oncol Biol Phys 88(3):715-722. doi:10.1016/j.ijrobp.2013.11.241

33. Stellamans K, Lievens Y, Lambin P, Van den Weyngaert D, Van den Bogaert W, Scalliet P, Hutsebaut L, Haustermans K (2002) Does sucralfate reduce early side effects of pelvic radiation? A double-blind randomized trial. Radiother Oncol 65(2):105-108

34. Athanassiou H, Antonadou D, Coliarakis N, Kouveli A, Synodinou M, Paraskevaidis M, Sarris G, Georgakopoulos GR, Panousaki K, Karageorgis P, Throuvalas N, Oncology Hellenic Group (2003) Protective effect of amifostine during fractionated radiotherapy in patients with pelvic carcinomas: results of a randomized trial. Int J Radiat Oncol Biol Phys 56(4):1154-1160. doi: 10.1016/s0360-3016(03)00187-1

35. Jahraus CD, Bettenhausen D, Malik U, Sellitti M, St Clair WH (2005) Prevention of acute radiation-induced proctosigmoiditis by balsalazide: a randomized, double-blind, placebo controlled trial in prostate cancer patients. Int J Radiat Oncol Biol Phys 63(5): 1483-1487. doi:10.1016/j.ijrobp.2005.04.032

36. Simone NL, Ménard C, Soule BP, Albert PS, Guion P, Smith S, Godette D, Crouse NS, Sciuto LC, Cooley-Zgela T, Camphausen K, Coleman CN, Singh AK (2008) Intrarectal amifostine during external beam radiation therapy for prostate cancer produces significant improvements in quality of life measured by EPIC score. Int J Radiat Oncol Biol Phys 70(1):90-95. doi:10.1016/j.ijrobp. 2007.05.057

37. Kneebone A, Mameghan H, Bolin T, Berry M, Turner S, Kearsley J, Graham P, Fisher R, Delaney G (2004) Effect of oral sucralfate on late rectal injury associated with radiotherapy for prostate cancer: a double-blind, randomized trial. Int J Radiat Oncol Biol Phys 60(4):1088-1097. doi:10.1016/j.ijrobp.2004.04.033

38. Koukourakis MI, Kyrgias G, Panteliadou M, Papadopoulou A, Tsiarkatsi M, Papachristou E, Bebeli M (2013) Dose escalation of amifostine for radioprotection during pelvic accelerated radiotherapy. Am J Clin Oncol 36(4):338-343. doi:10.1097/coc. 0b013e318248d882

39. Ferreira MR, Muls A, Dearnaley DP, Andreyev HJ (2014) Microbiota and radiation-induced bowel toxicity: lessons from inflammatory bowel disease for the radiation oncologist. Lancet Oncol 15(3):e139-e147. doi:10.1016/s1470-2045(13)70504-7

40. Nascimento M, Aguilar-Nascimento JE, Caporossi C, CastroBarcellos HM, Motta RT (2014) Efficacy of synbiotics to reduce acute radiation proctitis symptoms and improve quality of life: a randomized, double-blind, placebo-controlled pilot trial. Int $\mathrm{J}$ Radiat Oncol Biol Phys 90(2):289-295. doi:10.1016/j.ijrobp. 2014.05.049

41. Smeenk RJ, van Lin ENJT (2013) Application of anorectal sparing devices in prostate radiotherapy. Radiother Oncol 106(2):155156. doi:10.1016/j.radonc.2013.02.004

42. Van Lin EN, Kristinsson J, Philippens ME, de Jong DJ, Van DV, Kaanders JH, Leer JW, Visser AG (2007) Reduced late rectal mucosal changes after prostate three-dimensional conformal radiotherapy with endorectal balloon as observed in repeated endoscopy. Int J Radiat Oncol Biol Phys 67:799-811. doi:10.1016/j. ijrobp.2006.09.034

43. Hatiboglu G, Pinkawa M, Vallee JP, Hadaschik B, Hohenfellner M (2012) Application technique: placement of a prostate-rectum spacer in men undergoing prostate radiation therapy. BJU Int 110:e647-e652. doi:10.1111/j.1464-410x.2012.11373.x

44. Mok G, Benz E, Vallee JP, Miralbell R, Zilli T (2014) Optimization of radiation therapy techniques for prostate cancer with prostate-rectum spacers: a systematic review. Int J Radiat Oncol Biol Phys 90(2):278-288. doi:10.1016/j.ijrobp.2014.06. 044 
45. Pinkawa M (2014) Spacer application for prostate cancer radiation therapy. Future Oncol 10(5):851-864. doi:10.2217/fon.13.223

46. Schutzer ME, Orio PF, Biagioli MC, Asher DA, Lomas H, Moghanaki D (2015) A review of rectal toxicity following permanent low dose-rate prostate brachytherapy and the potential value of biodegradable rectal spacers. Prostate Cancer Prostatic Dis 18(2):96-103. doi:10.1038/pcan.2015.4

47. Prada PJ, Fernández J, Martinez AA, de la Rúa A, Gonzalez JM, Fernandez JM, Juan G (2007) Transperineal injection of hyaluronic acid in anterior perirectal fat to decrease rectal toxicity from radiation delivered with intensity modulated brachytherapy or EBRT for prostate cancer patients. Int J Radiat Oncol Biol Phys 69(1):95-102. doi:10.1016/j.ijrobp.2007.02.034

48. Wilder RB, Barme GA, Gilbert RF et al (2010) Cross-linked hyaluronan gel reduces the acute rectal toxicity of radiotherapy for prostate cancer. Int J Radiat Oncol Biol Phys 77(3):824-830. doi:10.1016/j.ijrobp.2009.05.069

49. Susil RC, McNutt TR, DeWeese TL et al (2010) Effects of prostate-rectum separation on rectal dose from external beam radiotherapy. Int J Radiat Oncol Biol Phys 76:1251-1258. doi:10. 1016/j.ijrobp.2009.07.1679

50. Noyes WR, Hosford CC, Schultz SE (2012) Human collagen injections to reduce rectal dose during radiotherapy. Int J Radiat Oncol Biol Phys 82(5):1918-1922. doi:10.1016/j.ijrobp.2011.02. 034

51. Pinkawa M, Corral NE, Caffaro M et al (2011) Application of a spacer gel to optimize three-dimensional conformal and intensity modulated radiotherapy for prostate cancer. Radiother Oncol 100(3):436-441. doi:10.1016/j.radonc.2011.09.005

52. Uhl M, van Triest B, Eble MJ, Weber DC, Herfarth K, De Weese TL (2013) Low rectal toxicity after dose escalated IMRT treatment of prostate cancer using an absorbable hydrogel for increasing and maintaining space between the rectum and prostate: results of a multi-institutional phase II trial. Radiother Oncol 106(2):215-219. doi:10.1016/j.radonc.2012.11.009

53. Melchert C, Gez E, Bohlen G et al (2013) Interstitial biodegradable balloon for reduced rectal dose during prostate radiotherapy: results of a virtual planning investigation based on the pre- and post-implant imaging data of an international multicenter study. Radiother Oncol 106(2):210-214. doi:10.1016/j.radonc.2013.01. 007

54. Song DY, Herfarth KK, Uhl M et al (2013) A multi-institutional clinical trial of rectal dose reduction via injected polyethyleneglycol hydrogel during intensity modulated radiation therapy for prostate cancer: analysis of dosimetric outcomes. Int J Radiat Oncol Biol Phys 87:81-87. doi:10.1016/j.jirobp.2012.12.019

55. Strom TJ, Wilder RB, Fernandez DC et al (2014) A dosimetric study of polyethylene glycol hydrogel in 200 prostate cancer patients treated with high-dose rate brachytherapy \pm intensity modulated radiation therapy. Radiother Oncol 111:126-131. doi:10. 1016/j.radonc.2014.02.011

56. Vanneste BG, Pijls-Johannesma M, Van De Voorde L, van Lin EN, van de Beek K, van Loon J, Ramaekers BL, Lambin P (2015) Spacers in radiotherapy treatment of prostate cancer: is reduction of toxicity cost-effective? Radiother Oncol 114(2): 276-281. doi:10.1016/j.radonc.2015.01.005

57. Denton A, Andreyev J, Forbes A, Maher EJ (2002) Non-surgical interventions for late radiation proctitis in patients who have received radical radiotherapy to the pelvis. Cochrane Database Syst Rev 1, CD003455. doi:10.1002/14651858.CD003455

58. Hanson B, MacDonald R, Shaukat A (2012) Endoscopic and medical therapy for chronic radiation proctopathy: a systematic review. Dis Colon Rectum 55(10):1081-1095. doi:10.1097/dcr. 0b013e3182587aef

59. Mendenhall WM, McKibben BT, Hoppe BS, Nichols RC, Henderson RH, Mendenhall NP (2014) Management of radiation proctitis. Am J Clin Oncol 37(5):517-523. doi:10.1097/coc. 0b013e318271blaa

60. Andreyev HJN, Davidson SE, Gillespie C et al (2012) Practice guidance on the management of acute and chronic gastrointestinal problems arising as a result of treatment for cancer. Gut 61(2): 179-192. doi:10.1136/gutjnl-2011-300563

61. Kochhar R, Patel F, Dhar A, Sharma SC, Ayyagari S, Aggarwal R, Goenka MK, Gupta BD, Mehta SK (1991) Radiation-induced proctosigmoiditis. Prospective, randomized, double-blind controlled trial of oral sulfasalazine plus rectal steroids versus rectal sucralfate. Dig Dis Sci 36(1):103-107. doi:10.1007/bf01300096

62. Kochhar R, Sriram PV, Sharma SC, Goel RC, Patel F (1999) Natural history of late radiation proctosigmoiditis treated with topical sucralfate suspension. Dig Dis Sci 44(5):973-978. doi: 10.1023/A:1026612731210

63. Cavcic J, Turcic J, Martinac P et al (2000) Metronidazole in the treatment of chronic radiation proctitis: clinical trial. Croat Med J 41:314-318

64. Ehrenpreis E, Jani A, Levitsky J et al (2005) A prospective, randomized, double-blind, placebo-controlled trial of retinol palmitate (vitamin A) for symptomatic chronic radiation proctopathy. Dis Colon Rectum 48:1-8. doi:10.1007/s10350-004-0821-7

65. Clarke RE, Tenorio LM, Hussey JR et al (2008) Hyperbaric oxygen treatment of chronic refractory radiation proctitis: a randomized and controlled double-blind crossover trial with long-term follow-up. Int J Radiat Oncol Biol Phys 72:134-143. doi:10. 1016/j.ijrobp.2007.12.048

66. Szabo S, Vattay P, Scarbrough E et al (1991) Role of vascular factors, including angiogenesis, in the mechanisms of action of sucralfate. Am J Med 91:S158-S160. doi:10.1016/00029343(91)90469-e

67. Hanauer SB (1990) Inflammatory bowel disease revisited: newer drugs. Scand J Gastroenterol Suppl 25(s175):97-106. doi:10. 3109/00365529009093133

68. Goodman LS, Gilman A (1996) The pharmacological basis of therapeutics, 9th edn. McGraw-Hill, New York, pp 995-998

69. Shadad AK, Sullivan FJ, Martin JD, Egan LJ (2013) Gastrointestinal radiation injury: prevention and treatment. World J Gastroenterol 19(2):199-208. doi:10.3748/wjg.v19.i2. 199

70. Kennedy M, Bruninga K, Mutlu EA, Losurdo J, Choudhary S, Keshavarzian A (2001) Successful and sustained treatment of chronic radiation proctitis with antioxidant vitamins $\mathrm{E}$ and $\mathrm{C}$. Am J Gastroenterol 96:1080-1084. doi:10.1111/j.1572-0241. 2001.03742.x

71. Feldmeier JJ, Hampson NB (2002) A systematic review of the literature reporting the application of hyperbaric oxygen prevention and treatment of delayed radiation injuries: an evidence based approach. Undersea Hyperb Med 29:4-30

72. Marx RE (1983) A new concept in the treatment of osteoradionecrosis. J Oral Maxillofac Surg 41:351-357. doi:10. 1016/s0278-2391(83)80005-6

73. Marx RE, Ehler WJ, Tayapongsak P et al (1990) Relationship of oxygen dose to angiogenesis induction in irradiated tissue. Am J Surg 160:519-524

74. Bennett MH, Feldmeier J, Hampson N, Smee R, Milross C (2012) Hyperbaric oxygen therapy for late radiation tissue injury. Cochrane Database Syst Rev 5, CD005005. doi:10.1002/ 14651858.CD005005.pub3

75. Kishan AU, Kupelian PA (2015) Late rectal toxicity after lowdose-rate brachytherapy: incidence, predictors, and management of side effects. Brachytherapy 14(2):148-159. doi:10.1016/j. brachy.2014.11.005

76. Phan J, Swanson DA, Levy LB, Kudchadker RJ, Bruno TL, Frank SJ (2009) Late rectal complications after prostate brachytherapy 
for localized prostate cancer: incidence and management. Cancer 115(9):1827-1839. doi:10.1002/cncr.24223

77. Farin G, Grund KE (1994) Technology of argon plasma coagulation with particular regard to endoscopic applications. Endosc Surg Allied Technol 2:71-77

78. Tjandra JJ, Sengupta S (2001) Argon plasma coagulation is an effective treatment for refractory hemorrhagic radiation proctitis. Dis Colon Rectum 44(12):1759-1765. doi:10.1007/bf02234451

79. Swan MP, Moore GT, Sievert W et al (2010) Efficacy and safety of single session argon plasma coagulation in the management of chronic radiation proctitis. Gastrointest Endosc 72:150-154. doi: 10.1016/j.gie.2010.01.065

80. Villavicencio RT, Rex DK, Rahmani E (2002) Efficacy and complications of argon plasma coagulation for hematochezia related to radiation proctopathy. Gastrointest Endosc 55(1):70-74. doi:10. 1067/mge.2002.119877

81. Karamanolis G, Triantafyllou K, Tsiamoulos Z, Polymeros D, Kalli T, Misailidis N, Ladas SD (2009) Argon plasma coagulation has a long-lasting therapeutic effect in patients with chronic radiation proctitis. Endoscopy 41(6):529-531. doi:10.1055/s-00291214726

82. Soussan BE, Mathieu N, Roque I, Antonietti M (2003) Bowel explosion with colonic perforation during argon plasma coagulation for hemorrhagic radiation-induced proctitis. Gastrointest Endosc 57(3):412-413. doi:10.1067/mge.2003.131

83. Taieb S, Rolachon A, Cenni JC et al (2001) Effective use of argon plasma coagulation in the treatment of severe radiation proctitis. Dis Colon Rectum 44(12):1766-1771. doi:10.1007/bf02234452

84. Canard JM, Védrenne B, Bors G et al (2003) Long term results of treatment of hemorrhagic radiation proctitis by argon plasma coagulation. Gastroenterol Clin Biol 27(5):455-459

85. Dees J, Maarten AC, Meijssen MA, Kuipers EJ (2006) Argon plasma coagulation for radiation proctitis. Scand J Gastroenterol Suppl 41(s243):175-178. doi:10.1080/00365520600664300

86. Fenwick JD, Khoo VS, Nahum AE, Sanchez-Nieto B, Dearnaley DP (2001) Correlations between dose-surface histograms and the incidence of long-term rectal bleeding following conformal or conventional radiotherapy treatment of prostate cancer. Int $\mathrm{J}$ Radiat Oncol Biol Phys 49(2):473-480

87. Rotondano G, Bianco MA, Marmo R et al (2003) Long-term outcome of argon plasma coagulation therapy for bleeding caused by chronic radiation proctopathy. Dig Liver Dis 35(11):806-810. doi:10.1016/s1590-8658(03)00454-7

88. Tam W, Moore J, Schoeman M (2000) Treatment of radiation proctitis with argon plasma coagulation. Endoscopy 32(9):667672. doi:10.1055/s-2000-9020

89. Zinicola R, Rutter MD, Falasco G, Brooker JC, Cennamo V, Contini S, Saunders BP (2003) Haemorrhagic radiation proctitis: endoscopic severity may be useful to guide therapy. Int $\mathrm{J}$ Color Dis 18(5):439-444. doi:10.1007/s00384-003-0487-y

90. Venkatesh KS, Ramanujam P (2002) Endoscopic therapy for radiation proctitis-induced hemorrhage in patients with prostatic carcinoma using argon plasma coagulator application. Surg Endosc 16(4):707-710. doi:10.1007/s00464-001-8164-0

91. Ravizza D, Giancarla F, Trovato C, Crosta C (2003) Frequency and outcomes of rectal ulcers during argon plasma coagulation for chronic radiation-induced proctopathy. Gastrointest Endosc 57(4): 519-525. doi:10.1067/mge.2003.144

92. Andreyev HJ (2007) Argon plasma coagulation in chronic radiation proctitis: Postgate et al. Endoscopy 39(8):751-752. doi:10. 1055/s-2007-966772

93. Andreyev HJ (2007) Gastrointestinal symptoms after pelvic radiotherapy: a new understanding to improve management of symptomatic patients. Lancet Oncol 8(11):1007-1017. doi:10.1016/ s1470-2045(07)70341-8
94. Sebastian S, O'Connor H, O'Morain C et al (2004) Argon plasma coagulation as first-line treatment for chronic radiation proctopathy. J Gastroenterol Hepatol 19(10):1169-1173. doi:10. 1111/j.1440-1746.2004.03448.x

95. Haas EM, Bailey HR, Farragher I (2007) Application of 10 percent formalin for the treatment of radiation-induced hemorrhagic proctitis. Dis Colon Rectum 50(2):213-217. doi:10.1007/s10350006-0707-y

96. Parikh S, Hughes C, Salvati EP, Eisenstat T, Oliver G, Chinn B, Notaro J (2003) Treatment of hemorrhagic radiation proctitis with 4 percent formalin. Dis Colon Rectum 46(5):596-600. doi:10. 1007/s10350-004-6614-1

97. Henson C (2010) Chronic radiation proctitis: issues surrounding delayed bowel dysfunction post-pelvic radiotherapy and an update on medical treatment. Ther Adv Gastroenterol 3(6):359-365. doi: $10.1177 / 1756283 \times 10371558$

98. Seow-Chen F, Goh H, Eu K, Ho Y, Tay S (1993) A simple and effective treatment for hemorrhagic radiation proctopathy using formalin. Dis Colon Rectum 36(2):135-138. doi:10.1007/ bf02051168

99. Biswal B, Lal P, Rath G, Shukla N, Mohanti B, Deo S (1995) Intrarectal formalin application, an effective treatment for grade III haemorrhagic radiation proctitis. Radiother Oncol 35(3):212215. doi:10.1016/0167-8140(95)01565-x

100. Saclarides T, King D, Franklin J, Doolas A (1996) Formalin installation for refractory radiation-induced hemorrhagic proctitis. Dis Colon Rectum 39(2):196-199. doi:10.1007/bf02068075

101. Roche B, Chauterns R, Marti M (1996) Application of formaldehyde for treatment of hemorrhagic radiation-induced proctitis. World J Surg 20(8):1092-1095. doi:10.1007/s002689900166

102. Counter S, Froese D, Hart M (1999) Prospective evaluation of formalin therapy for radiation proctitis. Am J Surg 177(5):396398. doi:10.1016/s0002-9610(99)00072-0

103. Luna-Pérez P, Rodríguez-Ramírez SE (2002) Formalin instillation for refractory radiation-induced hemorrhagic proctitis. J Surg Oncol 80(1):41-44. doi:10.1002/jso.10095

104. de Parades V, Etienney I, Bauer P, Bourguignon J, Meary N, Mory B, Sultan S, Taouk M, Thomas C, Atienza P (2005) Formalin application in the treatment of chronic radiation-induced hemorrhagic proctitis - an effective but not risk-free procedure: a prospective study of 33 patients. Dis Colon Rectum 48(8):15351541. doi:10.1007/s10350-005-0030-z

105. Raman RR (2007) Two percent formalin retention enemas for hemorrhagic radiation proctitis: a preliminary report. Dis Colon Rectum 50(7):1032-1039. doi:10.1007/s10350-007-0241-6

106. Sharma B, Kumar R, Singh KK, Chauhan V (2010) Intrarectal application of formalin for chronic radiation proctitis: a simple, cheap and effective treatment. Trop Gastroenterol 31(1):37-40

107. Nelamangala Ramakrishnaiah VP, Javali TD, Dharanipragada K, Reddy KS, Krishnamachari S (2012) Formalin dab, the effective way of treating haemorrhagic radiation proctitis: a randomized trial from a tertiary care hospital in South India. Color Dis 14(7): 876-882. doi:10.1111/j.1463-1318.2012.03008.x

108. Sánchez HA, del Vicente Sánchez MP, Arteta Jiménez M (2012) Formalin for haemorrhagic radiation-induced proctitis. Int J Color Dis 27(5):683-685. doi:10.1007/s00384-011-1268-7

109. Pironi D, Panarese A, Vendettuoli M, Pontone S, Candioli S, Manigrasso A, De Cristofaro F, Filippini A (2013) Chronic radiation-induced proctitis: the $4 \%$ formalin application as nonsurgical treatment. Int J Color Dis 28(2):261-266. doi:10.1007/ s00384-012-1571-y

110. Pikarsky AJ, Belin B, Efron J, Weiss EG, Nogueras JJ, Wexner SD (2000) Complications following formalin installation in the treatment of radiation-induced proctitis. Int J Color Dis 15(2):96-99. doi: $10.1007 / \mathrm{s} 003840050240$ 
111. Yeoh E, Tam W, Schoeman M, Moore J, Thomas M, Botten R, Di Matteo A (2013) Argon plasma coagulation therapy versus topical formalin for intractable rectal bleeding and anorectal dysfunction after radiation therapy for prostate carcinoma. Int J Radiat Oncol Biol Phys 87(5):954-959. doi:10.1016/j.ijrobp.2013.08.034

112. Alfadhli AA, Alazmi WM, Ponich T, Howard JM, Prokopiw I, Alaqeel A, Gregor JC (2008) Efficacy of argon plasma coagulation compared with topical formalin application for chronic radiation proctopathy. Can J Gastroenterol 22(2):129-132

113. De Palma GD (2009) Confocal laser endomicroscopy in the "in vivo" histological diagnosis of the gastrointestinal tract. World J Gastroenterol 15(46):5770-5775. doi:10.3748/wjg.15. 5770

114. Taylor JG, Disario JA, Bjorkman DJ (2000) KTP laser therapy for bleeding from chronic radiation proctopathy. Gastrointest Endosc 52(4):353-357. doi:10.1067/mge.2000.107726

115. Do NL, Nagle D, Poylin VY (2011) Radiation proctitis: current strategies in management. Gastroenterol Res Pract 2011:1-9. doi: $10.1155 / 2011 / 917941$
116. Lucarotti M, Mountford R, Bartolo D (1991) Surgical management of intestinal radiation injury. Dis Colon Rectum 34(10): 865-869. doi:10.1007/bf02049698

117. Yegappan M, Ho YH, Nyam D, Leong A, Eu KW, Seow C (1998) The surgical management of colorectal complications from irradiation for carcinoma of the cervix. Ann Acad Med Singap 27(5): 627-630

118. Fischer L, Kimose HH, Spjeldnaes N, Wara P (1990) Late progress of radiation-induced proctitis. Acta Chir Scand 156(11-12):801-805

119. Lane BR, Stein DE, Remzi FH, Strong SA, Fazio VW, Angermeier KW (2006) Management of radiotherapy induced rectourethral fistula. J Urol 175(4):1382-1387

120. Turina M, Mulhall AM, Mahid SS, Yashar C, Galandiuk S (2008) Frequency and surgical management of chronic complications related to pelvic radiation. Arch Surg 143(1):46-52. doi:10.1001/ archsurg. 2007.7 